\title{
High-flow nasal oxygen cannula vs. noninvasive mechanical ventilation to prevent reintubation in sepsis: a randomized controlled trial
}

\author{
Radhouane Toumi ${ }^{1,2+}$, Khaoula Meddeb ${ }^{1,2+}$ and Mohamed Boussarsar ${ }^{1,2^{*}}$ (1)
}

\begin{abstract}
Dear editor,
We read with great interest the article of Tongyoo et al. "High-flow nasal oxygen cannula vs. noninvasive mechanical ventilation to prevent reintubation in sepsis: a randomized controlled trial" published in Annals of Intensive Care [1]. The authors compared high-flow nasal oxygen cannula (HFNC) and noninvasive mechanical ventilation (NIV) as a ventilatory support in post-extubated sepsis patients seeking a reduction of the reintubation rate using HFNC. A few reservations could be considered.

We felt that the study could have followed a more comprehensive approach concerning acute respiratory failure, pulmonary mechanics and physiology of ventilatory management. This is particularly perceptible in front of the absence of data characterizing patients' neural drive and pulmonary mechanics, namely, airway pressures, airway collapsibility and respiratory system compliance and resistance [2], both prior and after extubation, which could identify a type of patients benefiting from NIV over HFNC and vice versa. Another important factor to assess, is the patient's psychological state which could
\end{abstract}

This comment refers to the article available online at https://doi.org/10.1186/ s13613-021-00922-5.

*Correspondence: hamadi.boussarsar@gmail.com

${ }^{\dagger}$ Radhouane Toumi and Khaoula Meddeb contributed as first authors

${ }^{1}$ Medical Intensive Care Unit, Farhat Hached University Hospital, Sousse,

Tunisia

Full list of author information is available at the end of the article be a cause of extubation failure and thereafter alter the adherence to a type of ventilatory support.

Secondly, the causes of reintubation presented by the authors could mostly be described as consequences of severe acute respiratory failure (hypoxia, inability to clear secretion, altered mental status, cardiac arrest, etc.), whereas it would have been more adapted to characterize the direct clinical causes of the respiratory failure such as, delirium, neuromuscular disorders, laryngeal edema, airways collapsibility, left heart failure, etc.

In our opinion, adapting different means of ventilatory support in accordance to the natural evolution of a disease, or in this particular case, according to the mechanism and severity of the post-extubation acute respiratory failure is more interesting than comparing one technique of ventilatory support to another. NIV is adapted in ARF associated with altered respiratory mechanics while HFNC is adapted to situations at risk of high patient-device interaction generating P-SILI (Patient Self-Inflicted Lung Injury).

Perhaps, taking into consideration the previously stated data, identifying a subgroup of patients presenting the same mechanism of post-extubation respiratory failure that would benefit from one technique rather than the other would be feasible and of great value.

Abbreviations

HFNC: High-flow nasal cannula; NIV: Noninvasive ventilation; P-SILI: Patient self-inflicted lung injury.
Springer Open

(c) The Author(s) 2021. Open Access This article is licensed under a Creative Commons Attribution 4.0 International License, which permits use, sharing, adaptation, distribution and reproduction in any medium or format, as long as you give appropriate credit to the original author(s) and the source, provide a link to the Creative Commons licence, and indicate if changes were made. The images or other third party material in this article are included in the article's Creative Commons licence, unless indicated otherwise in a credit line to the material. If material is not included in the article's Creative Commons licence and your intended use is not permitted by statutory regulation or exceeds the permitted use, you will need to obtain permission directly from the copyright holder. To view a copy of this licence, visit http://creativecommons.org/licenses/by/4.0/. 
Acknowledgements

None.

\section{Authors' contributions}

RT, KM, MB: substantial contributions to the critical appraisal of the paper, the letter conception and design, drafting the article and revising it critically for intellectual content. All authors read and approved the final manuscript.

\section{Funding}

None.

Availability of data and materials

None.

\section{Declarations}

Ethics approval and consent to participate

Not applicable.

\section{Consent for publication}

Not applicable.

\section{Competing interests}

The authors declare that they have no competing interests.

\section{Author details}

${ }^{1}$ Medical Intensive Care Unit, Farhat Hached University Hospital, Sousse,

Tunisia. ${ }^{2}$ Research Laboratory N LR12SP09. Heart Failure, Ibn Al Jazzar Faculty of Medicine, Farhat Hached University Hospital, University of Sousse., Sousse, Tunisia.

Received: 2 October 2021 Accepted: 22 November 2021

Published online: 13 December 2021

\section{References}

1. Tongyoo S, Tantibundit P, Daorattanachai K, Viarasilpa T, Permpikul C, Udompanturak S. High-flow nasal oxygen cannula vs. noninvasive mechanical ventilation to prevent reintubation in sepsis: a randomized controlled trial. Ann Intensive Care. 2021;11:135.

2. Boles JM, Blon J, Connors A, Herridge M, Marsh B, Melot C, et al. Weaning from mechanical ventilation. Eur Respir J. 2007;29:1033-56.

\section{Publisher's Note}

Springer Nature remains neutral with regard to jurisdictional claims in published maps and institutional affiliations.

\section{Submit your manuscript to a SpringerOpen ${ }^{\circ}$ journal and benefit from:}

- Convenient online submission

- Rigorous peer review

- Open access: articles freely available online

- High visibility within the field

- Retaining the copyright to your article

Submit your next manuscript at $\boldsymbol{\nabla}$ springeropen.com 